\title{
IDENTIFIKASI KESULITAN GURU PENDIDIKAN AGAMA BUDDHA DALAM MENGIMPLEMENTASIKAN KURIKULUM 2013 DI TANGERANG DAN DKI JAKARTA
}

\author{
Oleh: \\ Tri Amiro, Mulyana, Iin Suwarni, Yogi Murdianto \\ STABN Sriwijaya Tangerang Banten \\ demiro79@gmail.com
}

\begin{abstract}
This study aims to identify the difficulties experienced by Buddhist Education teachers in Tangerang and DKI Jakarta.The method used in this study is descriptive quantitative. Data collection techniques use the survey method. The instrument used to retrieve data consists of 125 items which are divided into 4 aspects, namely: 1) Scope of Curriculum 2013; 2) preparation of learning; 3) implementation of learning; and 4) evaluation. To guarantee the validity in the form of expert judgment, while the reliability of the Alpha Cronbach achievement index, which is equal to 0.989. The results obtained from this study are: 1) the difficulty level of Buddhist Education teachers in implementing 2013 Curriculum at 58.10\%; 2) the difficulty level of Buddhist Education teachers in implementing 2013 Curriculum on aspects around the 2013 Curriculum by 61.06\% ; 3) the difficulty level of Buddhist Education teachers in implementing 2013 Curriculum on aspects of learning preparation amounting to $59.91 \%$; 4) the difficulty level of Buddhist Education teachers in implementing 2013 Curriculum on the aspects of learning implementation is $55.32 \%$; and 5) the difficulty level of Buddhist Education teachers in implementing 2013 Curriculum on aspects of learning outcomes by $58.24 \%$, which are divided into three indicators: a) attitude size of $59.02 \%$; b) the amount of knowledge is $57.71 \%$; and c) the number of skills is $58.51 \%$;
\end{abstract}

Keywords: identification, difficulty, implementation, and curriculum.

\section{PENDAHULUAN}

Secara umum, pendidikan dapat dimaknai sebagai usaha yang dilakukan secara sadar oleh orang dewasa untuk mendidik, membina, dan melatih orang yang belum dewasa (anak-anak) sehingga mencapai kedewasaan ketika terjun dalam kehidupan bermasyarakat, berbangsa, dan bernegara. Pendidikan sangat dibutuhkan dalam mempersiapkan kompetensi generasi muda dalam menghadapi persaingan global. Dengan telah diberlakukannya Masyarakat Ekonomi ASEAN (MEA) yang disusul dengan masyarakat ekonomi Asia dan dunia, maka persaingan yang terjadi akan semakin ketat dan berat. Untuk menghadapi tantangan dan persaingan yang semakin berat tersebut, mutlak diperlukan generasi yang cerdas, cekatan, inovatif, dan kreatif. Untuk mencapai tujuan tersebut, diperlukan orang dewasa (sumber daya manusia) yang memiliki kompetensi dalam bidang pendidikan. Selain itu, diperlukan 
juga kurikulum yang representatif untuk merencanakan dan mengatur tujuan, isi, bahan, dan strategi dalam upaya mencapai tujuan pendidikan tersebut.

Dalam upaya memperloeh formulasi yang tepat dalam merencanakan dan mengatur tujuan, isi, bahan dan strategi dalam upaya mencapai tujuan pendidikan, serta terwujudnya Generasi Emas pada 100 tahun kemerdekaan Indonesia, maka pemerintah memberlakukan Kurikulum 2013 untuk pendidikan dasar dan menengah. Kurikulum 2013 tersebut berusaha untuk mengakomodasi perkembangan teknologi, pergeseran paradigma pembelajaran, dan keseimbangan aspek kognitif, psikomotorik, dan afektif dengan menerapkan pendekatan saintifik dalam pembelajaran.

Guru sebagai pengemban tugas mendidik siswa harus memiliki kemampuan dalam memahami dan mengimplementasikan isi dari kurikulum. Pemahaman yang baik tentang kurikulum nantinya mempermudah guru mengimplementasikan dalam pembelajaran. Kurikulum 2013 merupakan kurikulum yang relatif baru dalam penerapannya meskipun sempat diberlakukan sebelum dilakukan perubahan-perubahan yang cukup signifikan. Untuk dapat memahami isi dari kurikulum tersebut dibutuhkan waktu, sosialisasi, diskusi, workshop, dan pelatihan-pelatihan sehingga guru memiliki pengetahuan dan keterampilan yang memadai untuk mewujudkannya dalam pembelajaran.

Sampai saat ini, soasialisasi, diskusi, workshop, dan pelatihan-pelatihan mengenai kurikulum 2013 belum cukup memadai dalam memberikan pemahaman dan keterampilan bagi guru yang bertugas melaksanakan kurikulum tersebut. Dalam pelaksanaan kurikulum ini, masih sangat banyak pendukung-pendukung yang belum memadai dan dipersiapkan dengan matang, seperti dangkalnya pengetahuan yang diberikan dan format penilaian yang kompleks (http://suroboyo.id/dilema-k13-pada-jenjang-sekolah-dasar/). Permasalahan-permasalahan terse-but cukup mengganggu dan menghambat guru dalam melaksanakan pembelajaran.

Guru Pendidikan Agama Buddha merupakan salah satu pelaksana kurikulum 2013. Karena terlalu dipaksakan, sering termelihat pelaksanaan Kurikulum 2013 banyak menemui masalah, terutama masalah penilaian dan distribusi materi yang belum siap. Di samping itu, para guru juga belum mendapatkan pembekalan yang cukup untuk mengaplikasikan kurikulum tersebut (http:/ / buddhazine.com/apa-komentar-guru-agama-buddha-tentangpenghentian-kurikulum-2013).Kesulitan serupa juga dialami oleh guru Pendidikan Agama Buddha di Tangerang.Dari beberapa diskusi dengan guruguru Pendidikan Agama Buddha di Tangerang, ditemukan beberapa kesulitan yang menghambat guru dalam melaksanakan kurikulum 2013 seperti minimnya buku panduan, administrasi yang detail, dan perubahan sistem penilaian dari kurikulum sebelumnya. Dari beberapa permasalahan yang menyebabkan terhambatnya guru dalam implementasi Kurikulum 2013 di atas, maka perlu diidentifikasi kesulitan-kesulitan yang dialami guru dalam mengimplementasikan Kurikulum 2013, terutama pada guru Pendidikan Agama Buddha. 


\section{Kurikulum}

Kurikulum dapat dimaknai sebagai merencanakan dan mengatur tujuan, isi, bahan, dan strategi dalam upaya mencapai tujuan pendidikan. Romnie dalam Hamalik (2011: 4) curriculum is interpereted to mean all of the organized courses, activities, and experiences which pupils have under direction of school, whether in classroom. Kurikulum menurut pengertian tersebut merupakan interpretasi dari pengorganisasian pembelajaran, aktivitas, dan pengalaman yang dialami peserta didik melalui pengarahan pihak sekolah dan tidak hanya terbatas di dalam ruang kelas. Pembelajaran dapat dilaksanakan di mana pun dan kapan pun melalui pengarahan guru, baik secara langsung maupun tidak langsung. Dengan cara demikian, kegiatan yang dilakukan menjadi sangat bervariasi sehingga penglaman yang diperoleh peserta didik menjadi semakin langkap. Kurikulum menurut Hamalik (2010: 91) adalah rencana tertulis tentang kemampuan yang harus dimiliki berdasarkan standar nasional, materi yang perlu dipelajari dan pengalaman belajar yang harus dijalani untuk mencapai kemampuan tersebut, dan evaluasi yang diperlukan untuk menentukan tingkat pencapaian kemampuan peserta didik, serta seperangkat peraturan yang berkenaan dengan pengalaman belajar peserta didik dalam mengembangkan potensi dirinya pada satuan pendidikan tertentu. Tanner dan Tanner dalam Dimyati dan Mudjiono (2015: 264) mengaritikan konsep kurikulum sebagai: 1) pengetahuan yang diorganisasikan; 2) modus mengajar; 3) arena pengalaman; 4) pengalaman; 5) pengalaman belajar terbimbing; 6) kehidupan terbimbing; 7) rencana pembelajaran; 8) sistem produksi secara teknologis; dan 9) tujuan.

UU No. 20 Tahun 2003 tentang Sisetm Pendidikan Nasional Bab I pasal 1 ayat 19, mengartikan kurikulum sebagai seperangkat rencana dan pengaturan mengenai tujuan, isi, dan bahan pelajaran serta cara yang digunakan sebagai pedoman penyelenggaraan kegiatan pembelajaran untuk mencapai tujuan pembelajaran tertentu. Sagala (2012: 232) memaknai kurikulum sebagai usaha sekolah untuk mempengaruhi siswa agar dapat belajar dengan baik di dalam kelas, di halaman sekolah, di luar lingkungan sekolah, semua kegiatan untuk mempengaruhi subjek belajar sehingga menjadi pribadi yang diharapkan. Lattuca dan Stark dalam O'neill (2015: 7), curriculum is use of the concept of an academic plan, which focuses on planning processes, that includes eight elements: 1) purposes; 2) context; 3) sequence; 4) learners; 5) instructional processes; 6) instructional resources; 7) evaluation; and adjustment.

Pengertian kurikulum secara modern adalah semua kegiatan pengalaman potensial (isi/materi) yang telah disusun secara ilmiah baik yang terjadi di dalam kelas, di halaman sekolah, maupun di luar sekolah atas tanggung jawab sekolah untuk mencapai tujuan pendidikan (Arifin, 2017: 4). Dalam pengertian ini, kurikulum mengatur isi pembelajaran yang dapat berlangsung di mana saja dan kapan saja dibawah tanggung jawab sekolah dalam upaya mencapai tujuan pendidikan yang telah ditetapkan. Dengan demikian, kemampuan sekolah dalam menerjemahkan isi kurikulum sangat penting sekali sehingga mampu menciptakan situasi dan suasana yang kondusif untuk siswa dapat 
belajar sehingga tujuan pendidikan yang telah ditetapkan dapat tercapai dengan memaksimalkan seluruh potensi yang dimiliki.

Dari berbagai pengertian kurikulum di atas, maka dapat disimpulkan bahwa pengertian mengenai kurikulum sangat vervariasi bergantung pada ahli yang mendefinisikannya. Arifin (2017: 7) mengidentifikasi empat pengertian kurikulum yang di kenal selama ini, yaitu: 1) kurikulum idel (ideal curriculum); 2) kurikulum nyata (real curriculum or actual curriculum); 3) kurikulum tersembunyi (hidden curriculum); dan 4) kurikulum dan pembelajaran (curriculum and instructional). Kurikulum ideal merupakan kurikulum yang berisi sesuatu yang baik, yang diharapkan atau dicita-citakan, sebagaimana dimuat dalam dokumen kurikulum. Kurikulum nyata berisi mengenai kegiatan-kegiatan nyata yang dilakukan dalam proses pembelajaran atau yang menjadi kenyataan dari kurikulum yang direncanakan. Kurikulum tersembunyi merupakan segala sesuatu yang memengaruhi peserta didik secara positif ketika sedang mempelajari sesuatu. Kurikulum dan pembelajaran merupakan dua kata yang memiliki makna berbeda tetapi memiliki keterkaitan satu sama lain, dimana pembelajaran merupakan pengejawantahan isi dari kurikulum secara nyata.

\section{Pengembangan Kurikulum}

Kurikulum harus menyesuaikan dengan tututan zaman dan perkembangan ilmu pengethuan dan teknologi. Dengan alasan tersebut, maka kurikulum harus selalu direvisi. Kurikulum yang sudah ada dapat digunakan untuk melakukan pengembangan kurikulm. Sesuai dengan tuntutan zaman dan perkembangannya, kurikulum yang berlaku di Indonseia telah mengalami berbagai pengembangan dan penyesuaian. Saaat ini, kurikulum yang mulai diberlakukan adalah Kurikulum 2013 meskipun belum duterapkan di seluruh sekolah.

Dalam pengembangan kurikulum diperlukan landasan yang mendasarinya sebagai pijakan dalam melangkah. Hidayat (2015: 114) mengemukakan tiga aspek yang dapat digunakan sebagai landasan dalam mengembangkan kurikulum. Ketiga aspek tersebut, yaitu: 1) landasan filosofis; 2) landasan Yurudis; dan 3) landasan konseptual. Landasan filosofis didasarkan pada nilai-nilai luhur, nilai akademik, kebutuhan peserta didik dan masyarakat serta pengembangan kompetensi. Landasan yuridis yang digunakan didasarkan pada rencana jangka panjang maupun menengah yang telah ditetapkan sebelumnya. Dalam pengembangan Kurikulum 2013, landasan yurudis yang digunakan adalah Rencana Pembangunan Jangka Menengah Nasional (RPJMN) tahun 2014 (Hidayat, 2015: 115). Sedangan landasan konseptual yang diguanakan dalam pengembangan kurikulum adalah prinsip relevansi, yang mengacu pada kebutuhan dan tuntutuan perkembangan zaman.

Kurikulum harus selalu dikembangkan dan disesuaikan dengan tuntutan yang ada mengingat peran dan fungsi kurikulum yang sangat penting dalam menentukan tujuan dan arah penyelenggaraan pendidikan. Hamalik (2013: 11) 
mengidentifikasi tiga peran kurikulum, yaitu: 1) peran konservatif; 2) peran kritis atau evaluatif; dan 3) peran kreatif. Peran konservatif merupakan tanggung jawab kurikulum dalam mentransmisikan dan menafsirkan warisan sosial pada generasi muda, sehingga sekolah sebagai lembaga sosial dapat memengaruhi dan membina tingkah laku peserta didik sesuai dengan berbagai nilai sosial yang ada dalam masyarakat (Hamalik, 2013: 12). Peran kritis atau evaluatif menuntut kurikulum untuk selalu turut aktif dalam mengontrol dan memberikan pada unsur berpikir kritis (Hamalik, 2013: 12). Peran kreatif menuntut kurikulum untuk melakukan berbagai kegiatan kreatif dan konstruktif, dalam artian menciptakan dan menyusun suatu hal baru sesuaidengan kebutuhan masyarakat dimasa sekarang dan masa yang akan datang (Hamalik, 2013: 12-13).

Kurikulum juga memiliki fungsi tertentu. Inglis dalam Hamalik (2013: 1314) mengidentifikasi enam fungsi dari kurukulum, yaitu: 1) fungsi penyesuaian, di mana individu dapat menyesuaikan diri dengan lingkungan; 2) fungsi integrasi, di mana kurikulum berfungsi untuk mendidik pribadipribadi yang terintegrasi; 3) fungus diferensiasi, di mana kurikulum harus mampu memberikan pelayanan terhadap perbedaan-perbedaan yang dimiliki oleh individu-individu dalam masyarakat; 4) fungsi persiapan, di mana kurikulum harus mampu mempersiapkan peserta didik untuk dapat melanjutkan studi ke jenjang pendidikan yang lebih tinggii; 5) fungsi pemilihan, di mana kurikulum harus dapat nenyediakan pilihan bagi peserta didik untuk memilih pendidikan yang sesuai; dan 6) fungsi diagnostik $h$, dimana kurikulum harus dapat membantu dan mengarahkan peserta didik untuk memhami dan menerima dirinya sehingga dapat mengembangkan seluruh potensi yang dimilikinya.

Mulyasa (2017: 60-61) mengidentifikasn beberapa kelemahan yang harus diperbaiki dalam Kurikulum Tingkat Satuan pendidikan 2006 (KTSP) sehingga perlu dikembangkan, yaitu: 1) isi dan pesan-pesan dalam kurikulum masih terlalu padat; 2) kurikulum belum mengembangkan kompetensi secara utuh; 3) kompetensi yang dikembangkan lebih didominasi oleh aspek pengetahuan; 4) belum termuatnya beberapa kompetensi yang dibutuhkan sesuai dengan perkembangan masyarakat, seperti pendidikan karakter, kesadaran lingkungan, pendekatan dan metode pembelajaran konstruktif, keseimbangan soft skills dan hard skills, serta jiwa kewirausahaan; 5) kurikulum belum peka dn tanggap terhadap berbagai perubahan sosial; 6) standar proses pembelajaran belum menggambarkan urutan pembelajaran yang rinci; dan 7) penilaian belum menggunakan standar penilaian berbasis kompetensi. Hasil pengembangan Kurikulum 2006 tersebut saat ini mulai diberlakukan sebagai Kurikulum 2013. Selain itu, Kurikulum 2013 diharapkan mampu menciptakan lulusan yang berkarakter mulia dan berketerampilan yang relevan (Mulyasa, 2017: 61). Meskipun sudah berganti menjadi Kurikulum 2013, tetapi dasar dari penerapannya masih tetap mengaju pada kurikulum berbasis kompetensi sehingga kompetensi lulusan tetap menjadi tujuan utama. Mulyasa (2017: 6768) mengidentifikasi enam aspek atau ranah yang terkandung dalam konsep 
kompetensi, antara lain: 1) penegtahuan (knowledge) yang berarti kesadaran dalam bidang kognitif; 2) pemahaman (understanding) yang berarti kedalaman kognitif; 3) kemampuan (skills) sebagai sesuatu yang dimiliki oleh individu untuk melaksanakan tugas atau pekerjaan; 4) nilai (value) sebagai suatu standar perilaku yang telah diyakini dan secara psikologis telah menyatu dalam diri seseorang; 5) sikap (attitude) sebagai perasaan atau reaksi terhadap suatu rangsangan yang datang dari luar; dan minat (interest) yang berupa kecenderungan seseorang untuk melakukan suatu perbuatan.

\section{Kurikulum 2013}

Awalnya, Kurikulum 2013 diberlakukan secara serempak pada tahun 2014. Terjadinya pergeseran peran guru dalam pembelajaran menjadi salah satu alasan penundaan kembali implementasi Kurikulum 2013 dengan berbagai perbaikan. Pemahaman guru mengenai perbedaan Kurikulum 2013 dengan Kurikulum KTSP adalah berkenaan dengan adanya Kompetensi Inti. Mulyasa (2013: 3-4) Kurikulum 2013 memerinci Kompetensi Inti (KI) ke dalam empat kategori kemampuan, yaitu: KI-1 (sikap spiritual), KI-2 (sikap sosial), KI3 (pengetahuan), dan KI-4 (keterampilan). Hidayat (2015: 121) mengidentifikasi beberapa permasalahan lain yang mendasari pengembangan Kurikulum 2013, antara lain: 1) tantangan masa depan yang diantaranya meliputi arus globalisasi, masalah lingkungan hidup, kemajuan teknologi informasi, konvergensi ilmu dn teknologi, ekonomi berbasis pengetahuan, kebangkitan industry kreatif dan budaya, pergeseran kekuatan ekonomi dunia, pengaruh dan imbas teknosains, mutu, investasi dan transformasi pada sector pendidikan serta hasil TIMSS dan PISA; 2) kompetensi masa depan yang meliputi kemampuan berkomunikasi, kemampuan berpikir kritis, kemampuan mempertimbangkan segi moral suatu permasalahan, kemampuan menjadi warga negara yang efektif, dan kemampuan mencoba untuk mengerti dan toleran terhadap pandangan yang berbeda; dan 3) fenomena sosial yang mengemuka seperti perkelahian pelajar, narkoba, korupsi, plagiarism, kecurangan dalam berbagai jenis ujian, dan gejolak sosial.

Adanya pergeseran pola pikir dalam perumusan Kurikulum 2013 dari kurikulum sebelumnya, menuntut pula penyesuaian pada pendekatan yang digunakan dalam pembelajaran. Kurikulum 2013 menggunakan pendekatan saintifik dalam proses pembelajaran. Hosnan (2014: 34) mengartikan pendekatan saintifik sebagai proses pembelajaran yang dirancang sedemikian rupa agar peserta didik secara aktif mengkonstruk konsep, hukum atau prinsip melalui tahapan-tahapan mengamati (menemukan masalah), merumuskan masalah, mengajukan atau merumuskan hipotesis, mengumpulkan data dengan berbagai teknik, menganalisis data, menarik kesimpulan dan mengkomunikasikan konsep, hokum, atau prinsip ditemukan.

Hosnan (2014: 36) mengidentifikasi empat karakteristik pembelajaran dengan pendekatan saintifik, yaitu: 1) berpusat pada siswa; 2) melibatkan keterampilan proses sains dalam mengkonstruksi kosep, hukum atau prinsip; 3) melibatkan proses-proses kognitif yang potensial dalam merangsang 
perkembangan intelektual, khususnya keterampilan berpikir tingkat tinggi siswa; dan 4) dapat mengembangkan karakter siswa. Memalui pembelajaran yang menerapkan pendekatan saintifik, diharapakn dapat menghasilkan generasi yang mampu merespon tuntutan zaman, berpikir kritis, dan beranggung jawab.

Terdapat beberapa model pembelajaran yang dapat digunakan dalam implementasi pendekatan saintifik. Pendekatan dapat diartikan sebagai cara pandang untuk membelajarkan peserta didik melalui pusat perhatian tertentu (Akbar, 2013: 45). Terdapat tiga model pembelajaran yang cocok dalam implementasi kurikulum 2013, yaitu: 1) project based learning, 2) problem based learning, dan 3) inquirydiscovery based learning.

Warsono dan Hariyanto (2012: 149) menyatakan bahwa pembelajaran berbasis masalah merupakan suatu tipe pengelolaan kelas yang diperlukan untuk mendukung pendekatan konstruktivisme dalam penganaran dan belajar. Savoie dan Hughes dalam Warsono dan Hariyanto (2012: 149-150) mengungkapkan pelunya proses yang dapat digunakan untuk mendesain pengalaman belajar berbasis masalah bagi siswa, yang memuat langkahlangkah sebagai berikut: 1) identifikasi suatu masalah yang cocok bagi siswa; 2) mengaitkan masalah tersebut dengan konteks dunia siswa; 3) mengorganisasikan pokok bahasan di sekitar masalah; 4) memberikan tanggung jawab kepada siswa untuk mendefinisikan sendiri pengalaman belajar serta membuat perencanaan dalam menyelesaikan masalah; 5) mendorong timbulnya kolaborasi dengan membentuk kelompok pembelajaran; dan 6) memberikan dukungan kepada siswa untuk mendemonstrasikan hasilhasil pembelajaran. Selain itu, akan diperoleh berbagai keuntungan atau kekuatan dengan menggunakan problem based learning. Warsono dan Hariyanto (2012: 152) mengidentifikasi empat keunggulan dari pembelajaran berbasis masalah, yaitu: 1) siswa akan terbiasa menghadapi masalah; 2) memupuk solidaritas sosial dengan terbiasa berdiskusi dengan teman-teman sekelompok; 3) meningkatkan keakraban dengan teman dan guru; dan 4) adanya suatu kemungkinan suatu masalah harus diselesaikan melalui eksperimen sehingga membiasakan siswa untuk membiasakan diri menerapkan metode tersebut.

Model pembelajaran inkuiri menekankan kepada proses pencarian dan penemuan. Majid (2016: 222) mengemukakan bahwa pembelajaran inkuiri merupakan serangkaian kegiatan pembelajaran yang menekankan pada proses berpikir kritis dan analitis untuk mencari dan menemukan sendiri jawaban dari suatu masalah yang dipertanyakan. Selanjutnya, Majid (2016: 222) mengemukakan tiga ciri dari pembeljaran inkuiri, yaitu: 1) memekankan kepaa aktivitas siswa secara maksimal untuk mencari dan menemukan; 2) seluruh aktivitas siswa diarahkan untuk mencari dan menemukan jawaban sendiri dari sesuatu yang dipertanyakan sehingga diharapkan dapat menumbuhkan sikap percaya diri; dan 3) tujuan dari pembelajaran inkuiri adalah mengembangkan kemampuan berpikir secara sistematis, logis, dan kritis, atau mengembangkan kemampuan intelektual sebagai bagian dari proes mental. 
Ada beberapa prinsip yang digunakan dalam menerapkan model pembelajaran inkuiri. Majid (2016: 223- 224) mengemukakan lima prinip penggunaan pembelajaran inkuiri, yaitu: 1) berorientasi pada pengembangan intelektual; 2) prinsip interaksi; 3) prinsip bertanya; 4) prinsip belajar untuk berpikir; dan prinsip keterbukaan. Dalam mengimplementasikan prmbelajaran inkuiri, terdapat enam langkah yang perlu diikuti (Majid, 2016: 224-226), yaitu: 1) orientasi; 2) merumuskan masalah; 3) merumuskan hipotesis; 4) mengumpulkan data; 5) menguji hipotesis; dan merumuskan kesimpulan. Penggunaan pembelajaran inkuairi memiliki berbagai keunggulan. Majid (2016: 227) mengidentifikasi empat keunggulan dari pembelajaran inkuiri, yaitu: 1) menekankan pengembangan aspek kognitif, afektif, dan psikomotor secara seimbang sehingga pembelajaran menjadi lebih bermakna; 2) memberikan ruang kepada siswa untuk belajar sesuai gaya belajarnya; 3) sesuai dengan perkembangan psikologi belajar modern yang menganggap belajar sebagai proses perubahan tingkahlaku berkat adanya pengalaman; dan 40 melayani kebutuhan siswa yang memiliki kemampuan di atas rata-rata.

\section{Kompetensi Guru}

Guru sebagai pelaku utama dalam proses pendidikan harus mampu memahami dan mengimplementasikan kurikulum sebagai landasan dalam melaksanakan pembelajaran. Nurdin dan Usman dalam Supardi (2013: 153) mengemukakan bahwa salah satu indikator keberhasilan guru dalam pelaksanaan tugasnya adalah dapatnya guru menjabarkan, memperluas, menciptakan relevansi kurikulum dengan kebutuhan peserta didik dan perkembangan serta kemajuan ilmu pengetahuan dan teknologi. Dengan demikian, kemampuan guru dalam memahami isi kurikulum dan memerapkannya dalam proses pembelajaran sehingga dapat memenuhi kebutuhan siswa dengan memanfaatkan kemajuan ilmu pengetahuan dan teknologi mutlak diperlukan dalam menjamin keberhasilan proses pembelajaran.

Kompetensi adalah perbuatan, perilaku, atau performansi yang menunjukkan kecakapan, kebisaan (ableness), atau peran secara standar seperti yang dituntut oleh suatu okupasi, pekerjaan atau profesi (Sukmadinata dan Syaodih, 2012: 39). Kompetensi menggambarkan kemampuan bertindak yang dilandasi dengan ilmu pengetahuan yang hasil dari tindakan itu bermanfaat bagi dirinya dan orang lain (Nurfuadi, 2012: 71). Performance merupakan perilaku nyata yang tidak hanya diamati, tetapi juga meliputi perihal yang tidak tampak (Uno dan Lamatenggo: 12). Pasal 10 Ayat 1 UU No. 14 Tahun 2013 mensyaratkan empat kompetensi yang harus dimiliki oleh seorang guru, yaitu: 1) pedagogik; 2) keperibadian; 3) sosial; dan 4) profesional. Kompetensi pedagogik berkaitan dengan kemampuan guru dalam memahami peserta didik dan melaksanakan pembelajaran. Secara substansi, kompetensi pedagogik mencakup kemampuan pemahaman terhadap siswa, perencanaan dan pelaksanaan pembelajaran, evaluasi hasil belajar, dan pengembangan siswa untuk mengaktualisasikan berbagai potensi yang dimilikinya 
(Suprihatiningrum, 2013: 101). Soediarto dalam Uno dan Lamatenggo (2016: 15) mengidentifikasi beberapa hal yang harus dikuasai oleh guru professional, antara lain: 1) disiplin ilmu pengetahuan sebagai sumber bahan pelajaran; 2) bahan ajar yang diajarkan; 3) pengetahuan tentang karakteristik siswa; 4) pengetahuan tentang filsafat dan tujuan pendidikan; 5) pengetahuan dan penguasaan metode dan model pembelajaran; 6) penguasaan terhadap prinsipprinsip teknologi pembelajaran; dan 7) pengetahuan terhadap penilaian dan mampu merencanakan, serta memimpin guna kelancaran proses pendidikan.

Kompetensi kepribadian adalah kompetensi yang berkaitan dengan perilaku pribadi guru yang kelak harus memiliki nilai-nilai luhur sehingga terpancar dalam perilaku sehari-hari (Alma, 2010: 136). Dengan demikian, kompetensi kepribadian berkaitan dengan internal diri guru. Guru dengan kompetensi kepribadian yang baik mampu memberikan teladan bagi peserta didiknya. Kompetensi sosial merupakan kemampuan guru dalam memahami dirinya sebagai bagian dari yang tak terpisahkan dari masyarakat yang memiliki kemampan, keterampilan yang cukup luas, ikut secara aktif dalam proses pembangunan (Alma, 2010: 137). Guru yang merupakan bagian dari masyarakat harus mampu memberikan kontribusi terhadap perkembangan dan kemajuan pada masyarakat. Sumbangsih guru dalam bentuk nyata dapat berupa pemikiran, ide, dan gagasan serta tindakan nyata dalam perbuatan dala memecahkan permasalahan sosial.

Usman dalam Suprihatiningrum (2013: 114) menyebutkan bahwa kompetensi professional menggambarkan tentang keampuan yang harus dimiliki oleh seseorang yang mengampu jabatan sebagai seorang guru, yaitu kemampuan yang ditampilkan itu menjadi ciri keprofesionalannya. Lebih lanjut, Suprihatiningrum (2013: 115) menjelaskan bahwa kompetensi professional sebagai keampuan yang berkaitan dengan penguasaan materi pembelajaran bidang studi secara luas dan mendalam yang mencakup peguasaan substansi keilmuan yang menaungi materi dalam kurikulum, serta menambah keilmuan sebagai guru. Cooper dalam Alma (2013: 138) menyebutkan empat komponen kompetensi professional, yaitu: 1) mempunyai pengetahuan tentang belajar dan tingkah laku manusia; 2) mempunyai pengetahuan dan menguasai bidang studi yang dibinannya; 3) mempunyai sikap yang tepat tentang diri sendiri, sekolah, teman sejawat, dan bidang studi yang dibinanya; dan 4) mempunyai keterampilan dalam teknik mengajar.

\section{Kompetensi tentang Kurikulum 2013}

Kinerja guru sangat berkaitan erat dengan standar beban kerja yang harus dipenuhi. UU No. 14 Tahun 2005 tentang Guru dan Dosen pasal 35 menyebutkan bahwa beban kerja guru meliputi tiga tugas pokok, yaitu merencanakan, melaksanakan, dan menilai hasil pembelajaran serta memberikan bimbingan dan pelatihan ditambah dengan tugas tambahan. Untuk dapat merencanakan, melaksanakan, dan melakukan penilaian hasil belajar, guru harus memiliki pemahaman yang cukup mengenai kurikulum. Dengan demikian, pemahaman dan penguasaan mengenai isi kurikulum 
menjadi syarat mutlak bagi guru sehingga dapat merencanakan, melaksanakan, dan melakukan penilaian dengan tepat.

Kurikulum 2013 adalah kurikulum competency based sangat ditentukan oleh kemmpuan guru dalam mengembangkan perangkat pembelajaran, yaitu pengembangan silabus, buku ajar, sumber dan media pembealajaran, model pembelajaran, instrument asesmen, dan RPP (Akbar, 2013: 2). Sebelum menyusun rencana pembelajaran, uru terlebih dahulu harus mengembangkan silabus. Departemen Pendidikan Nasional (2008) dalam Akbar (2013: 7) mendefinisikan silabus sebagai rencana pembelajaran pada satu dan/atau kelompok mata pelajaran/tema tertentu yang mencakup standar kompetensi (kompetensi inti), kompetensi dasar, materi pemeblajaran, kegiatan pembelajaran, indikator pencapaian kompetensi, penilaian, alokasi waktu, dan sumber belajar. Dalam praktiknya, guru tinggal mengembangkan/menurunkan kompetensi dasar menjadi indikator sebagai penanda keberhasilan pembelajaran, dimana indicator tersebut berfungsi untuk mengembagkan tujuan pembelajaran, substansi materi, sumber dan media, serta alat penilaian (Akbar, 2013: 10). Sementara itu, Sasmiatin dalam (Akbar, 2013: 10) menyebutkan langkah pengembangan indikator dapat dilakukan dengan cara sebagai berikut: a) setiap KD dapat dikembangkan menjadi beberapa indicator; b) perumusan indikator menggunakan kata kerja operasional yang dapat diukur dan/atau diobservasi; c) tingkat kata kerja dalam indikator lebih rendah atau setara dengan kata kerja dalam KD; d) menggunakan prinsip urgesi, kontinuitas, relevansi, dan kontekstual; dan e) seluruh indikator KD merupakan tanda untuk pencapaian kompetensi dasar yakni terealisasikannya nilai, sikap, kemampuan berpikir, dan bertindak secara konsisten. Munthe (2009: 35) menyebutkan syarat dalam menyusun indicator pencapaian harus bersifat: dapat diukur, dapat dievaluasi, dapat dicapai, dan dapat dibuktikan.

\section{Pelaksanaan Pembelajaran}

Secara umum, kegiatan pembelajaran dibagi menjadi 3 tahap, yaitu pendahuluan (prainstruksional), inti, dan penutup. Berkaitan dengan tahap pembelajaran, Majid (2016: 27-32) mengemukakan tiga tahap pembelajaran, yaitu: 1) prainstruksional; 2) instruksional; dan 3) penilaian dan tindak lanjut. Dalam pelaksanaan pembelajaran, Amri (2013: 53-54) mengemukakan beberapa persyaratan yang harus dipenuhi, antara lain: besar rombbongan belajar, beben kerja minimal guru, ketersediaan buku teks pelajaran, dan pengelolaan kelas.

Tahap prainstruksional adalah tahapan yang ditempuh guru pada saat memulai proses pembelajaran (Majid, 2016: 27). Berkenaan dengantahap prainstruksional, Azril (2010: 70) mengungkapkan bahwa inti persoalan membuka kegiatan pembelajaran terkait dengan usaha guru dalam menarik perhatian, motivasi, memberi acuan tujuan pembelajaran, pokok persoalan yang akan dibahas, rencana kerja serta pembagian waktu, mengaitkan pelajaran yang telah dipelajari dengan topik baru, dan menanggapi situasi kelas. Majid (2016: 27-28) mengemukakan beberapa aktivitas yang dapat 
dilakukan dala prainstruksional, antara lain: 1) menanyakan kehadiran dan mencatat siswa yang tidak hadir; 2) menanyakan kepada siswa mengenai batas pemelajaran yang lalu; 3) memberikan pertanyaan kepada siswa materi pemelajaran yang lalu; 4) memberikan kesempatan kepada siswa untuk menanyakan hal-hal yang belum jelas mengenai materi pemelajaran yang lalu; dan mengulang kembali bahan pembelajaran sebelumnya secara singkat.

Kegiatan instruksional atau kegiatan inti merupakan proses pembelajaran untuk mencapai tujuan pembelajaran yang sudah ditetapkan. Amri (2013: 55) menyatakan bahwa kegiatan inti merupakan proses pembelajaran untuk mencapai kompetensi dasar yang dilakukan secara interaktif, inspiratif, menyenangkan menantang, memotivasi peserta didik untuk berpartisipasi aktif, serta memberikan ruang yang cukup bagi prakarsa, kreativitas, dan kemandirian sesuai dengan bakat, minat dan perkembangan fisik serta psikologis peserta didik, melalui proses eksploratif, elaboratif, dan konfirmasi. Majid (2016: 28-29) mengidentifikasi beberapa kegiatan yang dapat dilakukan pada tahap inti, yaitu: 1) menjelaskan pada siswa tujuan pembelajaran; 2) menuliskan pokok materi; 3) membahas pokok materi; 4) memberikan contohcontoh konkret; 5) penggunaan alat bantu pengajaran untuk menjelaskan; dan menyimpulkan hasil pembahasan dari pokok materi.

Kegiatan penutup merupakan kegiatan yang tidak kalah pentingnya dalam pembelajaran. Kegiatan penutup harus dikemas sedemikian rupa sehingga memberikan penguatan bagi siswa mengenai apa yang telah dipelajari. Amri (2013: 57) menyebutkan beberapa kegiatan yang dapat dilakukan pada tahap penutup, yaitu: 1) bersama-sama dengan siswa dan/atau sendiri membuat rangkuman/simpulan pembelajaran; 2) melakukan penilaian dan/atau refleksi terhadap kegiata yang sudah dilaksanakan secara konsisten dan terprogram; 3) memberikan umpan balik terhadap proses dan hasil pembelajaran; 4) merancang kegiatan tindak lanjut dalam bentuk pembelajaran remidi, program pengayaan, layanan konseling dan/atau memberikan tugas, baik individu maupun kelompok sesuai dengan hasil belajar peserta didik; dan menyampaikan rencana pembelajaran pada pertemuan berikutnya.

\section{Evaluasi pembelajaran}

Untuk mengetahui keberhasilan suatu pembelajaran perlu dilakukan penilaian atau evaluasi. Berkaitan dengan penilaian dalam pembelajaran, Sudjana (2017: 1) mengemukakan bahwa terdapat tiga sasaran pokok, yaitu program pendidikan, proses belajar-mengajar, dan hasil-hasil belajar. Seorang guru mata pelajaran mutlak melakukan penilaian berkaitan dengan pelaksanaan dan hasil belajar. Dalam melakukan penilaian ini, ada beberapa prinsip yang harus diikuti. Majid (2016: 336-337) mengemukakan 9 prinsip penilaian, yaitu: 1) sahih, yaitu penilaian didasarkan pada data yang mencerminkan kemampuan yang diukur; 2) objektif, yaitu penilaian didasarkan pada prosedur dan kriteria yang jelas, dan tidak terpengaruh oleh subjektivitas penilai; 3) adil, yang berarti penilaian tidak menguntungkan atau merugikan peserta didik; 4) terpadu, yang berarti penilaian merupakan salah 
satu komponen yang tidak gterpisahkan dari kegiatan pembelajaran; 5) terbuka, yang berarti bahwa prosedur, kriteria, dan dasar pengambilan keputusan dapat diketahui oleh pihak yang berkepentingan; 6) menyeluruh dan berkesinambungan, yang berarti penilaian mencakup semua aspek kompetensi; 7) sistematis, yang berarti penilaian dilakukan secara terencana dan bertahap; 8) beracuan kriteria, yang berarti penilaian didasarkan pada ukuran pencapaian kompetensi; dan 9) akuntabel, yang berarti penilaian dapat dipertanggungjawabkan, baik dari segi prosedur maupun hasilnya.

\section{Identifikasi Kesulitan}

Perubahan kurikulum yang diberlakukan oleh pemerintah menuntut guru untuk dapat menyesuaikan diri dengan cepat berkenaan dengan makna filosofis dan isi dari kurikulum tersebut. Tidak setiap guru mampu dengan cepat memahami maksud dari isi kurikulum baru. Kesulitan dalam menerjemaahkan isi kurikulum juga menambah beban guru, terutama bagi guru-guru yang sudah mapan dengan kurikulum sebelumnya. Kesulitan guru tersebut dapat menghambat kinerja guru dalam melaksanakan proses pembelajaran.

Sugono, dkk. (2008: 538) mengartikan identidikasi sebagai perbuatan menetapkan identitas seseorang, benda dan sebagainya. Sedangkan kesulitan diartikan sebagai keadaan yang sulit, sesuatu yang sulit, kesukaran atau kesulitan (Sugono, dkk., 2008: 1386). Dengan demikian identifikasi kesulitan dapat diartikan sebagai upaya untuk menetapkan kesukaran atau kesulitan yang dialami seseorang. Dalam penelitian ini, yang dimaksud dengan identifikasi kesulitan adalah upaya untuk mengetahui kesulitan yang dialami guru Pendidikan Agama Buddha dalam mengimplementasikan Kurikulum 2013. Aspek kesulitan yang akan diketahui dalam penelitian ini berkenaan dengan penguasaan mengenai kurikulum 2013, perencanaan, pelaksanaan, dan evaluasi pembelajaran.

\section{METODE PENELITIAN}

Penelitian tentang "Identifikasi Kesulitan Guru Pendidikan Agama Buddha dalam Mengimplementasikan Kurikulum 2013 di Tangerang, Kota Tangerang dan DKI Jakarta", menggunakan metode penelitian deskriptif kuantitatif. Sulistyo Basuki (2006: 110) mengemukakan bahwa penelitian deskriptif dapat dilakukan secara kuantitatif agar dapat dilakukan analisis statistik. Metode survey adalah metode penelitian kuantitatif yang digunakan untuk mendapatkan data yang terjadi pada masa lampau atau saat ini, tentang keyakinan, pendapat, karakteristik, perilaku, hubungan variabel dan untuk menguji beberapa hipotesis tentang variabel sosiologis dan psikologis dari sampel yang diambil dari populasi tertentu (Sugiyono, 2013: 24). Penelitian survei sering kali digunakan dalam ilmu sosial untuk membantu melakukan pengamatan terhadap suatu fenomna sosial (Morissan, 2014: 165). Salah satu alasan penggunaan penelitian survey dalam penelitian ini adalah seperti yang 
dikemukanan oleh Morissan (2014: 166) bahwa penelitian survey merupakan salah satu metode terbaik yang tersedia bagi para peneliti sosial yang tertarik untuk mengumpulkan data guna menjelaskan suatu populasi yang terlalu besar untuk diamati secara langsung.

\section{HASIL DAN PEMBAHASAN}

Pembahasan hasil penelitian akan disesuaikan dengan tahap pengolahan data, yaitu: 1) tingkat kesulitan secara keseluruhan; 2) tingkat kesulitan dalam aspek kompetensi tentang Kurikulum 2013; 3) tingkat kesulitan dalam aspek persiapan pembelajaran; 4) tingkat kesulitan dalam aspek pelaksanaan pembelajaran; dan 5) tingkat kesulitan dalam aspek penilaian pembelajaran.

Berdasarkan pengolahan data yang berasal dari 80 orang responden, hasil penelitian menunjukkan bahwa tingkat kesulitan guru Pendidikan Agama Buddha dalam mengimplementasikan Kurikulum 2013 sebesar 58,10\%. Dari angka tersebut menunjukkan bahwa tingkat kesulitan yang dialami guru Pendidikan Agama Buddha masih cukup besar (lebih dari 50\%). Dari 80 orang responsen tersebut digolongkan menjadi tiga kelompok, diperoleh hasil: 15 orang atau 18,8\% mengalami kesulitan tinggi, 58 orang atau $72,5 \%$ mengalami kesulitan sedang, dan 7 orang atau 8,8\% mengalami kesulitan rendah.

Dari hasil tersebut, hanya sedikit guru Pendidikan Agama Buddha yang benar-berar mampu mengimplementasikan Kurikulum 2013 dengan baik dengan tingkat kesulitan rendah, yaitu kurang dari 10 persen. Sedangkan guru Pendidikan Agama Buddha yang mengalami kesulitan dalam mengimplementasikan Kurikulum 2013 tergolong cukup tinggi, yaitu 15 orang atau mencapai $18,8 \%$. Tingkat kesulitan yang cukup tinggi ini dapat disebabkan karena adanya sedikitnya program sosialaisasi dan pelatihan bagi guru Pendidikan Agama Buddha berkenaan dengan Kurikulum 2013. Selain sedikitnya program sosialisasi dan pelatihan, tingkat kesulitan yang cukup tinggi tersebut dikarenakan tidak meratanya pemberian kesempatan untuk mengikuti program sosialisasi dan pelatihan tersebut. Akibatnya, guru yang telah mampu mengimplementasikan Kurikulum 2013 dengan baik akan semakin baik, tatapi guru yang belum mampu tidak bertambah baik kemampuannya dalam mengimplementasikan kurikulum tersebut.

Dilihat dari aspek kompetensi mengenai Kurikulum 2013, diperoleh hasil bahwa tingkat kesulitan dalam penguasaan kurikulum sebesar $61,06 \%$. Hasil tersebut menunjukkan bahwa guru Pendidikan Agama Buddha masih memiliki tingkat kesulitan yang tinggi dalam pemahaman dan penguasaan Kurikulum 2013. Kesulitan yang dialami guru dalam pemahaman dan penguasaan mengenai kurikulum akan memberikan dampak pada tahap implementasi di lapangan.

Jika dirinci lebih mendetail, tingkat kesulitan yang dialami guru Pendidikan Agama Buddha dalam penguasaan Kurikulum 2013 terletak pada indikator model pembelajaran, yaitu sebesar $62,81 \%$. Penyebab tingginya tingkat kesulitan guru dalam menguasi model pembelajaran adalah model pembelajaran yang biasa digunakan belum memenuhi pola pembelajaran 
dengan pendekatan saintifik. Umumnya, pembelajaran yang dilaksanakan guru adalah model klasikal yaitu dengan metode ceramah. Besarnya tingkat kesulitan dalam penguasaan kurikulum berkenaan dengan indikator model pembelajar memberikan sumbangan yang sangat siknifikan terhadap tingkat kesulitan dalam penguasaan kurikulum. Dari hasil pengolahan data diperoleh hasil bahwa tingkat kesulitan guru dalam menguasai model pembelajaran yang sesuai dengan Kurikulum 2013 paling tingggi diantar indikator lainnya, yang mencapai 29 orang atau 36,3\% guru yang masih mengalami kesulitan tinggi.

Tingkat kesulitan guru Pendidikan Agama Buddha dalam hal persiapan pembelajaran sebesar 59,91\%. Dari pengolahan data diperoleh hasil bahwa guru Pendidikan agama Buddha yang mengalami kesulitan tinggi untuk aspek persiapan pembelajaran adalah 12 orang atau 15,0\% guru. Sedangkan guru yang tidak mengalami kesulitan dalam mempersiapkan pembelajaran sebesar 7 orang atau 8,8\%. Dengan demikian, tingkat kesulitan yang dialami guru dalam mempersiapkan pembelajaran berada pada tingkat sedang, yaitu 61 orang atau $76,3 \%$.

Apabila dilihat lebih rinci berdasarkan indikator-indikatornya, maka diperoleh hasil bahwa tingkat kesulitan yang paling tinggi adalah dalam menyiapkan materi pembelajaran, yaitu sebesar $64,17 \%$. Dari hasil ini menunjukkan bahwa sebagian besar guru Pendidikan Agama Buddha masih kesulitan dalam memilih materi pembelajaran yang cocok dengan karakteristik Kurikulum 2013 untuk diimpelmentasikan dalam pembelajaran. Biasanya guru hanya menggunakan materi pembelajaran seperti yang ada di dalam buku cetak yang sudah tersedia.

Tingginya tingkat kesulitan guru dalam menyiapkan materi pembelajaran juga didukung fakta bahwa persentase guru yang kesulitan dalam tingkat tinggi paling besar terdapat pada indikator materi pembelajaran yang mencapai $43,8 \%$ atau sebanyak 35 guru. Dari hasil tersebut dapat diketahui bahwa hampir setengah dari responden masih mengalami kesulitan dalam memilih dan menyiapkan materi pembelajaran yang tepat.Tingkat kesulitan guru dalam aspek pelaksanaan pembelajaran sebesar $55,32 \%$. Jika dibandingkan dengan aspek-aspek yang lain, maka aspek pelaksanaan pembelajaran merupakan aspek yang memberikan kontribusi tingkat kesulitan yang paling kecil, yaitu sebesar 55,32\%. Kontribusi yang kecil ini juga didukung dari hasil pengelompokan, dimana hanya 7 orang atau $8,8 \%$ guru yang masih mengalami kesulitan pada tingkat tinggi.

Dilihat dari indikatornya, kesulitan guru paling menonjol (terbesar) dalam melaksanakan pembelajaran berada pada indikator kegiatan inti, yaitu sebesar 58,53\%. Kegiatan inti merupakan proses pembelajaran yang memungkinkan tercapainya tujuan pembelajaran yang telah ditetapkan, tanpa mengesampingkan peran kegiatan pendahuluan dan penutup. Meskipun demikian, berdasarkan indikatornya, kesulitan terbesar yang dialami guru dalam pelaksanaan pembelajaran berada pada indikator pengelolaan pembelajaran, di mana guru yang mengalami kesulitan tingggi sebanyak 21 orang atau $26,3 \%$. 
Kesulitan guru dalam aspek evaluasi atau penilaian pembelajaran sebesar $58,24 \%$. Berdasarkan kriteria pengelompokan, terdapat 8 orang atau $10,0 \%$ guru yang masih mengalami kesulitan tinggi. Kurikulum 2013 menuntut guru untuk dapat melakukan penilaian secara seimbang dalam tiga aspek pembelajaran yang dikembangkan, yaitu: sikap, pengetahuan, dan keterampilan. Dari hasil pengolahan data diperoleh hasil bahwa indikator penilaian sikap memeberikan sumbangan terbesar dalam tingkat kesulitan aspek penilaian pembelajaran, yaitu sebesar 59,02\%. Dari kurikulum sebelumnya, guru sudah terbiasa melakukan penilaian berkaitan dengan ranah pengetahuan dan keterampilan. Dalam implementasi Kurikulum 2013, guru harus terampil dalam melaksanakan penilaian dalam ketiga aspek atau ranah tersebut. Selain itu, aspek sikap juga menjadi perhatian yang cukup serius, di mana Kompetensi Inti (KI) yang pertama adalah sikap, baik spiritual maupun sosial. Dengan demikian, guru harus benar-benar menguasai penilaian dalam aspek sikap.

Dilihat dari masing-masing indikator, tingkat kesulitan guru paling tinggi berada pada indikator penilaian keterampilan, yaitu sebesar 18 orang atau 22,5\%. Dari hasil tersebut menunjukkan bahwa secara umum guru masih mengalami kesulitan dalam melaksanakan penilaian berkaitan dengan ranah afektif dan psikomotorik. Sistem penilaian dalam Kurikulum 2013 menuntut penilaian afektif dan psikomotorik menggunakan instrumen penilaian yang baik memberikan kesulitan tersendiri bagi guru untuk menyusun instrumen maupun dalam melaksanakan penilaian.

\section{SIMPULAN}

Dari hasil penelitian dan pembahasan, maka dari penelitian ini dapat ditarik beberapa kesimpulan, yaitu:Tingkat kesulitan guru Pendidikan Agama Buddha dalam mengimplementasikan Kurikulum 2013 sebesar 58,10\%.Tingkat kesulitan guru Pendidikan agama Buddha dalam mengimplementasikan Kurikulum 2013 pada aspek kompetensi tentang kurikulum sebesar 61,06\%, dengan rincian per indikator sebagai berikut: a. Karakteristik kurikulum sebesar 61,88\%; b. Model pembelajaran sebesar 62,81\%; c. Penilaian pembelajaran sebesar $61,02 \%$; dan d. KKM sebesar 59,69\%.Tingkat kesulitan guru Pendidikan agama Buddha dalam mengimplementasikan Kurikulum 2013 pada aspek persiapan pembelajaran sebesar $61,06 \%$, dengan rincian per indikator sebagai berikut: a) RPP sebesar 60,31\%; b) Materi pembelajaran sebesar $64,17 \%$; c) Kegiatan pembelajaran sebesar 59,91\%; kecakapan yang dikembangkan sebesar 60,25\%; Media dan sumber pembelajaran sebesar 57,19\%; dan f. Penilaian sebesar 58,54\%.Tingkat kesulitan guru Pendidikan agama Buddha dalam mengimplementasikan Kurikulum 2013 pada aspek pelaksanaan pembelajaran sebesar 55,32\%, dengan rincian per indikator sebagai berikut: a) Pengelolaan pembelajaran sebesar 53,59\%; b) Kegiatan pendahuluan sebesar 53,82\%; c) kegiatan inti sebesar 58,53\%; d) Kegiatan penutup sebesar 50,21\%; e) Media dan sumber pembelajaran sebesar 54,65\%; dan kecakapan yang dikembangkan sebesar $57,95 \%$. 
Tingkat kesulitan guru Pendidikan agama Buddha dalam mengimplementasikan Kurikulum 2013 pada aspek penilaian pembelajaran sebesar 58,24\%, dengan rincian per indikator sebagai berikut: a) Penilaian sikap sebesar 59,02\%; b) Penilaian pengetahuan sebesar 57,71\%; dan c) penilaian keterampilan sebesar $58,51 \%$.

\section{DAFTAR PUSTAKA}

Akbar, Sa'dun. 2013. Instrumen Perangkat pembelajaran. Bandung: Remaja Rosdakarya.

Alma, Buchari. 2010. Guru Profesional: Menguasai Metode dan Trampil Mengajar. Bandung: Alfa Beta.

Amri, Sofan. 2013. Pengembangan dan model Pembelajaran dalam Kurikulum 2013. Jakarta: Prestasi Pustakaraya.

Dimyati dan Mudjiono. 2015. Belajar dan Pembelajaran. Jakarta: Rineka Cipta.

Hamalik, Oemar. 2010. Manajemen Pengembangan Kurikulum. Bandung: Remaja Rosdakarya.

2011. Dasar-Dasar Pengembangan kurikulum. Bandung: Remaja Rosdakarya.

2013. Dasar-dasar Pengembangan Kurikulum. Bandung: Remaja Rosdakarya.

Hidayat, Sholeh. 2015. Pengembangan Kurikulum Baru. Bandung: remaja

Rosdakarya.

Hosnan, M. 2014. Pendekatan saintifik dan Kontekstual dalam Pembelajaran Abad 21:

Kunci Sukses Implementasi Kurikulum 2013. Bogor: Ghalia Indonesia.

Majid, Abdul. 2016. Strategi pembelajaran. Bandung: Remaja Rosdakarya.

Morissan. 2014. Metode Penelitian Survey. Jakarta: Kencana.

Mulyasa, H.E. 2017. Pengembangan dan Implementasi Kurikulum 2013. Bandung:

Remaja Rosdakarya

Nurfuadi. 2012. Profesionalisme Guru. Purwokerto: STAIN Press.

O'neill, Geraldine. 2015. Curriculum design In Higher Education: Theory to Practice

(eBook). Dublin: UCD teaching and Learning.

Sagala, Syaiful. 2012. Konsep dan Makna Pembelajaran. Bandung: Alfabeta.

Sudjana, Nana. 2017. Penilaian Hasil proses belajar Mengajar. Bandung: Remaja Rosdakarya.

Sugono, Dendy. 2008. Kamus Besar Bahasa Indonesia. Jakarta: Pusat Bahasa Departemen Pendidikan Nasional.

Sukmadinata, Nana Syaodih dan Erliana Syaodih. 2012. Kurikulum dan Pembelajaran Kompetensi. Refika Aditama.

Supardi. 2013. Kinerja Guru. Jakarta: RajaGrafindo Persada.

Suprihatiningrum, Jamil. 2013. Guru Profesional: Pedoman Kinerja, Kualifikasi, dan Kompetensi Guru. Yogyakarta: Ar-Ruzz Media

Warsono dan Hariyanto. 2012. Pembelajaran Aktif: Teori dan asesmen. Bandung: Remaja Rosdakarya.

Uno, Hamzah B. dan Nina Lamatenggo. 2016. Tugas Guru dalam Pembelajaran Aspek yang Memengaruhi. Jakarta: Bumi Aksara. 